DOI https://doi.org/10.32689/maup.philol.2021.2.7

УДК 81 '42

\title{
Яна ШВЕЦЬ
}

викладач кафедри теорії та практики перекладу, Івано-Франківський національний технічний університет нафти й газу, вул. Карпатська, 15, м. Івано-Франківськ, Україна, 76019 ORCID: 0000-0003-1863-5027

\section{Yana SHVETS}

Lecturer, Department of Translation Theory and Practice, Ivano-Frankivsk National Technical University of Oil and Gas, str. Karpatska, 15, Ivano-Frankivsk, Ukraine, 76019

ORCID: 0000-0003-1863-5027

\section{ВЕРБАЛЬНА ОБ'СКТИВАЦІЯ ПРЕЦЕДЕНТНИХ ОСОБИСТОСТЕЙ В КОНЦЕПТУАЛЬНОМУ ДОМЕНІ «АРТУРІВСЬКА ЖІНКА»}

\section{VERBAL OBJECTIFICATION OF PRECEDENT PERSONALITIES IN THE CONCEPTUAL DOMAIN "ARTHURIAN WOMAN"}

Кониептуальний домен «артурівська жінка» найширие представлений у текстах легенд про короля Артура XV-XXI cm. Його понятійний субстрат представляє собою одну з жіночих особистостей, яка відігравала значну роль в житті та діяльності легендарного короля Артура, щзо профілізується в досліджуваному дискурсі XV-XXI cm. у ПО Guinevere, Morgana i Lady of the Lake. Mетою cmammi є дослідження вербальноі об' єктивачї̈ преицедентних особистостей в концеептуальному домені «артурівська жінка». Наукова новизна. Преиедентні жіночі особистості являють собою певні соціокультурні типи / «модельні особистості», головною ознакою яких є відображення иіннісних орієнтирів поведінки. Вони є концептами «типізованої особистості», образом, створеним на основі соиіокультурних критеріїв і специфічних характеристик вербальної та невербальної поведінки. Поряд із ичим вони постають і як узагальнені образи особистості, чия поведінка та иіннісні орієнтири, відчутно впливаючи на лінгвокультуру в иілому, є показниками етнічної та соціальної своєрідності суспільства. Висновки. У підсумку статті виділено жіночі прецедентні особистості Guinevere, MorGana, Lady of the Lake, які складають кониептуальний домен «артурівська жінка» у легендах про короля Артура, та проаналізовано лінгвістичні особливості їх актуалізаціі

Ключові слова: концеептуальний домен, прецедентна особистість, легенди про короля Артура, номінація.

The conceptual domain "Arthur's woman" is most widely represented in the texts of legends about King Arthur $X V-X X I$ centuries. His conceptual substratum is one of the female personalities who played a significant role in the life and work of the legendary King Arthur, which is profiled in the studied discourse of the XV-XXI centuries. in the software of Guinevere, Morgana and Lady of the Lake. The aim of the article is to study the verbal objectification of precedent personalities in the conceptual domain "Arthurian woman". Scientific novelty. Precedent female personalities are certain socio-cultural types / "model personalities", the main feature of which is the reflection of values of behavior. They are concepts of "typified personality", an image created on the basis of socio-cultural criteria and specific characteristics of verbal and nonverbal behavior. Along with this, they appear as generalized images of the individual, whose behavior and values, significantly influencing the linguistic culture in general, are indicators of ethnic and social identity of society. Conclusions. As a result of the article, female precedents Guinevere, MorGana, Lady of the Lake, who make up the conceptual domain "Arthur's woman" in the legends of King Arthur, are highlighted, and the linguistic features of their actualization are analyzed.

Keywords: conceptual domain, precedent personality, legends about King Arthur, nomination.

Актуальність проблеми. Об'єктом цієї роботи $\epsilon$ прецедентні особистості (ПО), предметом - їхня вербалізація в концептуальному домені «артурівська жінка», що разом зумовлюють й основну мету розвідки - вербальна об'єктивація жіночих прецедентних особистостей в дискурсі легенд про короля Артура. Відповідно, постають і такі конкретні завдання: з'ясувати номенклатуру концептуального домену «артурівська жінка», визначити лінгвальні особливості їхньої репрезентації та актуалізації в артурівському дискурсі.

Мета статті - дослідити вербальну об'єктивацію прецедентних особистостей в концептуальному домені «артурівська жінка».

Виклад основного матеріалу. Концептуальний домен «артурівська жінка» найширше представлений у текстах легенд про короля Артура XV-XXI ст. Його понятійний субстрат представляє собою одну з жіночих особистостей, яка відігравала значну роль в житті 
та діяльності легендарного короля Артура, що профілізується в досліджуваному дискурсі XV-XXI ст. у ПО Guinevere, Morgana i Lady of the Lake.

Прецедентні жіночі особистості являють собою певні соціокультурні типи / «модельні особистості», головною ознакою яких є відображення ціннісних орієнтирів поведінки [3, с. 87]. Вони є концептами «типізованої особистості», образом, створеним на основі соціокультурних критеріїв і специфічних характеристик вербальної та не- вербальної поведінки $[5$, с. 6]. Поряд із цим вони постають і як узагальнені образи особистості, чия поведінка та ціннісні орієнтири, відчутно впливаючи на лінгвокультуру в цілому, $\epsilon$ показниками етнічної та соціальної своєрідності суспільства [2, с. 5].

Прецедентна особистість Guinevere пов'язана із легендарністю, мудрістю та відданістю Двору королеви. Номінація Guinevere походить від валлійського Gwenhwyfar (Gwenh - 'примара', wyfar'білий'). В істоpiï монаха Джеффрі Монмутського "Historia Regum Britanniae" / «Історія королів Британії» (1135-1137), ім'я Гвіневіри транслітерувалося як Guanhumara, а вже у творах Середньовіччя зустрічаються форми Guinevere, Guenevere та Genievre на позначення дружини короля Артура. Ці форми фігурують зараз в бри- танській художній літературі.

У британській літературі XVI-XVIII ст. ПО Guinevere згадується в одинадцяти з 27 творів, виявляючи різні образно-оцінні характеристики, які не обов'язково наявні у словниках, але 3 достатньою частотністю використовуються в текстах Артуріани.

Говорячи про образно-оцінний субстрат ПО Guinevere, встановленого на основі прецедентного тексту (ПТ) Т. Мелорі «Смерть Артура», не можна не помітити, що воно має ніби дві іпостасі. Перша традиційно апелює до таких характеристик, як «жінка», «дружина», «королева». Друга виявляється пов'язаною з похітливими характеристиками ПО Guinevere, а саме, «коханка», «зрадниця», «руйнівниця Камелоту». Образно-оцінний шар ПО Guinevere виявляє в ряд образних характеристик як позитивного (шляхетність, привітність, вишуканість, строгість, могутність, відданість, краса), так і негативного (чужоложство, зрада) гатунку, що разом сприяють валоризації прецедентної особистості Guinevere в лінгвокультурі Британії.

3 огляду на валоративний чинник, концептуальна структура ПО Guinevere постає у діаді: позитивно-оцінного (краса (faire queene dame Guenever, beauteous consort, exquisite beauty, beautiful Queen), могутність (they were received by the Queen in the most affectionate manner), шляхетність (gracious Queen), величність (Your Majesty), доброта (goodly Queene Guenever), негативного (чужоложство («This Queen of England was in love with Lancelot of the Lake»; «...when Lancelot of the Lake, the favourite of Queen Genievre») факторів конституювання.

Зазначені оцінно-образні характеристики ПО Guinevere $\epsilon$ базисними для сучасного англомовного дискурсу. Про це свідчать, зокрема, дані $\mathrm{BNC}$, де зафіксовано одинадцять випадків використання Guinevereномінацій, п'ять 3 яких є результатом вторинної і шість - первинної. Внаслідок утворення лексем способом вторинної номінації в сучасному дискурсі відбувається збагачення лексеми «Guinevere» та навантаження іiї новими лексичними значеннями, зокрема у двох позиціях, що були виявлені у творах XXI ст. жіноче ім'я та назва сорту троянд.

Отже, ПО Guinevere представляє собою ко- ролеву Камелоту, кохану жінку Ланселота, основними характеристиками якої є мудрість, краса та могутність. Це ПО внутрішньо суперечливе і багатозначне. 3 огляду на валоративний чинник, концептуальна структура ПО Guinevere постає у діаді: позитивно-оцінного (шляхетність, краса, величність, доброта), негативного (чужоложство) факторів свого конституювання. Співвідношення полюсно протилежних ознак ПО є різним.

ПО Guinevere виступає цікавим об'єктом дослідження в артурівських легендах, що обумовлено тим фактом, що жінка в епоху правління Артура займала особливе місце у лицарському товаристві, а це відповідно, знайшло своє вираження і у мові.

Не менш цікавим для лінгвістичного аналізу $є$ прецедентні особистості фейрі, що символізують напівжінок-напівфей, які причаровували лицарів Круглого Столу, володіли вмінням зцілення та чаклунства. Артурівські фейрі - це безумовно fata MorGana тa Lady of the Lake.

Прецедентна особистість Fata Morgana, що є легендарною постаттю розповідей про короля Артура, виступає в різних іпостасях: як цілителька, як чарівниця, як фейрі та навіть, як богиня. Образно-оцінну складову досліджуваної ПО можна встановити на основі фахових джерел, де вона постає в двох іпостасях: як зведена сестра Артура по матері, яка проживала на острові Авалон та як цілителька, ворожка, богиня та навіть фетрі.

У британській літературі XVI - XVII ст. ПО MorGana не згадується в артурівському 
дискурсі, і лише в XVIII - XXст. можна виявити різні образно-оцінні характеристики досліджуваної прецедентної особистості, які 3 достатньою частотністю використовуються в текстах Артуріани (згадка досліджуваного ПО у тринадцяти творах).

Образно-оцінний субстрат ПО MorGana, представлений також двома іпостасями: позитивні: чесність (fair a lady), могутність іiі чар (by enchantment) та негативні - підступність (cunning Morgan le Fay).

3 огляду на валоративний чинник, концептуальна структура цього ПО постає у триєдності: позитивного (магічність (dazzling witch), доброчесність (virtuous Morgana), витонченість (a ladye subtle, proud, and wise), та негативного (підступність (coward Morgan), ворожість (winding her fingers into the woman's hair, gave her a cuff that would have set), чорна магія (Morgan, Lady of Shadowland), злість (lute Morgan, despicable Morgana) факторів конституювання. Кількісне співвідношення цих полюсно протилежних рубрик оцінки майже однакове.

У BNC зафіксовано 6 випадків використання Morgana-номінацій, і лише одна 3 них $\epsilon$ результатом первинної номінації. Вторинні номінації, побудовані за мотивами оцінної образності ПО MorGana, трапляються в сучасному англійському публіцистичному та офіційно-діловому мовленні. Отже, ПО MorGana представляє собою чаклунку-фею Моргану, основними характеристиками якої $\epsilon$ магічні вміння, ворожість та краса.

Прецедентна особистість Lady oF the Lake асоціюється в легендах про короля Артура 3 мечем Excalibur, який Володарка Озера подарувала Артуру, коли він зійшов на престол. Однак в артурівському дискурсі Lady of the Lake не належить до якогось певного індивідуума, а є почесним титулом хранительки-чаклунки, який може переходити від однієї жінки до іншої. Саме магічність та містичність образу відносить Lady of the Lake до прецедентних особистостей, що представлені жіночими прецедентними іменами Nimue та Viviane. На основі дефініцій взятих із фахових джерел можна виділити такі три ознаки прецедентної особистості Lady of the Lake: титул володарки озера, яким володіла чаклунка Вівіан; кохана Мерліна, який підддавшись іiї чарам навчив магії та згубив своє життя та жінка, яка вихову- вала маленького Ланселота, а потім зробила його одним 3 лицарів Круглого Столу. Саме на основі цих характеристик формується образно-оцінна структура аналізованого ПО.
Ознаки, що встановлені на основі прецедентного твору Т. Мелорі «Смерть Артура» формують поняттєвий каркас ПО Lady of the Lake, зокрема «загадковість», «могутність», «привітність», «підступність» та «жорстокість».

Артурівський дискурс XVI-XVIII ст. фіксує використання ПО Lady of the Lake у трьох творах цього періоду. Досліджуваний ПО об'єктивує при цьому три характерні ознаки, що формують образний каркас: «могутність» (vigorous Lady of the Lake), «підступність» (had seized the sage in his sleep, enchanted and confined him in a tomb) та «зрадливість» (perfidious Lady of the Lake).

Для сучасної англійської лінгвокультури вербалізація досліджуваного ПО є також актуальною проблемою. Контексти BNC фіксують 8 випадків використання Lady of the Lake-номінацій, три 3 яких є результатом вторинної і лише п'ять - первинної. Вторинні номінації, побудовані за мотивами оцінної образності ПО Lady of the Lake і зафіксовані в BNC, трапляються в сучасному англійському публіцистичному та неакадемічному мовленні. Не можна не помітити, що вони базуються на традиційній оцінно-образній ознаці концепту (історичність), яка вербалізується в назві квітів, художніх творів, п’єси, кафе/pecторану.

Отже, ПО Lady of the Lake представляє собою титул Володарки Озера, що вербалізується поряд із іншими прецедентними особистостями. Цей ПО внутрішньо суперечливий i багатозначний. 3 огляду на валоративний чинник, концептуальна структура ПО Lady of the Lake постає у триєдності позитивно-оцінного (загадковість, могутність, привітність), так і негативного (жорстокість, підступність) та нейтрально-оцінного (історичність) факторів свого конституювання. Співвідношення полюсно протилежних ознак ПО $є$ майже однаковими,

Отже, аналіз ПО Lady of the Lake вказує на той факт, що як і інші прецедентні особистості артурівського дискурсу, ця лексема міцно закріпилася в британській літературі, актуалізуючи первинно закладені ознаки у творах XVI-XX ст., та обросла в сучасному британському дискурсі новими оцінними характеристиками, що призводять до появи вторинної номінації Lady of the Lake-лексеми.

Висновки та пропозиції. Підводячи підсумок, зазначимо, що: 1) прецедентні особистості Guinevere, MorGana та Lady of the Lake $\epsilon$ постаттями легендарного світу, головною ознакою яких є відображення ціннісних ознак жіночих постатей британського лінгвокуль- 
турного простору, які формують концептуальний домен «артурівська жінка», Досліджувані ПО виступають показниками етнічних та лінгвокультурних знань та знаходять своє мовне вираження в контекстах британської культури XVI-XXI ст.;

2) зміст та структура цих ПО актуалізується через значення мовних одиниць, що їх репрезентують, а також словникові дефініції і мовленнєві контексти. Дані лексикографічних джерел, праці британських і американських вчених, присвячених вивченню артурівської символіки, вказують на культурну активність та значеннєвість досліджуваних жіночих прецедентних особистостей. Первинне значення, закладене ПТ Т.Мелорі «Смерть Артура», а також символьні характеристики встановлені на його основі, актуалізуються протягом XVI-XX ст. незмінними, обростаючи однак у XXI ст. новими оцінними ознаками; 3) цін- нісна складова досліджуваних ПО постає в триєдності: позитивно - оцінних, нейтральнооцінних та іноді негативно-оцінних факторів конституювання. Співвідношення полюсно протилежних ознак у відсотковому відношенні $є$ майже однаковим; 4) прецедентні особистості Guinevere, MorGana та Lady of the Lake формують 5 гендерних бінарних жіночих стереотипів, тобто судженню з негативною оцінкою протиставляється судження 3 позитивною:《доброта» vs «злість», «відьмарство», «підступність» vs «привітність», «ніжність»; «чужоложство», «спокусливість», «загадковість» vs «закоханості»; «злість» vs «благородність»; «підступність» vs «чесність»; «могутність» vs «жіночність». BNC фіксує використання досліджуваних ПО у 5 типах дискурсу: розмовному, художньому, офіційно-діловому, науковому та публіцистичному.

\section{Література:}

1. Вежбицкая А. Язык. Культура. Познание. Пер. с англ. и отв. ред. М.А. Кронгауз. Москва : Русские словари, 1996. 712 с.

2. Дмитриева О.А. Лингвокультурные типажи России и Франции XIX века: Автореф. дис. доктора филол. наук / Волгоградский гос. пед. ун-т. Волгоград, 2007. 24 с.

3. Карасик В.И. Лингвокультурный типаж. Язык. Текст. Дискурс: Научный альманах Ставропольского отделения Общероссийской общественной организации «Российская ассоциация лингвистовкогнитологов» / Под ред. Г.Н. Манаенко, Вып. 5. Ставрополь : ПГЛУ, 2007. С. 86-89.

4. Карасик В.И. Языковой круг: личность, концепты, дискурс. Волгоград : Перемена, 2002. 477 с.

5. Селиверстова Л.П. Лингвокультурный типаж «звезда Голливуда» : автореф. дис. канд. филол. наук / Волгоградский гос. ун-т. Волгоград, 2007. 19 с.

6. Thomas Malory. Le Mort d'Arthur. URL: http://www.gutenberg. org/ebooks/1251.

\section{References:}

1. Vezhbitskaya, A. (1996) Yazyk. Kul'tura. Poznanie. [Language. Culture. Cognition]. Translation from English. and resp. ed. M.A. Kronhaus. Moscow: Russian Dictionaries. 712 p.

2. Dmitrieva, O.A. (2007) Lingvokul'turnye tipazhi Rossii i Frantsii XIX veka [Linguo-cultural types of Russia and France of the XIX century] Extended abstract of Doctor's thesis. Volgograd. Volgograd State Pedagogical University. 24 p.

3. Karasyk, V.Y. (2007) Lynhvokulturnyi typazh. Yazyk Tekst. [Linguocultural type. Language. Text]. Dyskurs: Nauchnyi almanakh Stavropolskoho otdelenyia Obshcherossyiskoi obshchestvennoi orhanyzatsyy "Rossyiskaia assotsyatsyia lynhvystov-kohnytolohov" - Discourse: Scientific Almanac of the Stavropol Branch of the All-Russian Public Organization "Russian Association of Linguists and Cognitologists" Ed. G.N. Manaenko, no. 5. Stavropol. P. 86-89.

4. Karasik, V.I. (2002) Yazykovoy krug: lichnost', kontsepty, diskurs [Language circle: personality, concepts, discourse]. Volgograd: Peremena, 2. $477 \mathrm{p}$.

5. Seliverstova, L.P. (2007). Lingvokul'turnyy tipazh "zvezda Gollivuda" [Linguocultural type "Hollywood star"] Extended abstract of candidate's thesis. Volgograd: Volgograd State University. 19 p.

6. Thomas Malory. Le Mort d'Arthur. Retrieved from: http://www.gutenberg. org/ebooks/1251. 